Received 11 June 2019, Accepted 20 July 2019

Link to DOI:

10.25220/WNJ.V03.i1.0004 Journal Website: www.worldnutrijournal.org

\section{An Overview of Hydration Status and Its Relation to Occupational Heat Stress among Workers}

\author{
Ade Mutiara $^{1}$, Ray Wagiu Basrowi ${ }^{1}$, Saptawati Bardosono ${ }^{2}$ \\ 1. Association of Occupational Medicine Magister, Faculty of Medicine, Universitas Indonesia \\ 2. Department of Nutrition, Faculty of Medicine, Universitas Indonesia
}

\begin{abstract}
Working in high temperature environment is unavoidable condition for an outdoor worker, especially the outdoor workers in to tropical countries such as Indonesia. Heat stress leads to various heat-related illnesses, such as heat stroke, hyperthermia, heat exhaustion, heat cramps or heat rashes. A mild and moderate heat stress usually less serious and did not harm general health condition, however it could cause individual fatigue and unfocused, which will interfere the working performance and productivity. Numbers of studies showed that there were strong correlation between occupational related heat stress and workers' hydration status. Unfortunately, there were still very limited recommendation and guideline specifically regulated the importance of hydration toward outdoor worker as well as those who were working in high temperature working environment.

Keywords heat stress, heat-related illness, workers, hydration
\end{abstract}

\section{Introduction}

Working in high temperature environment is unavoidable condition for an outdoor worker, especially for outdoor worker in tropical countries such as Indonesia as well as worker in industry dealing with hot temperature environment. The similar environment also applies to worker in industry or factories with extremely high temperature and heated environment. A study in Indonesia reported that during 2012 - 2013 there were numerous of heat and high temperature occupational exposure cases in Indonesia, which

\footnotetext{
Corresponding author:

Ray Wagiu Basrowi

Association of Occupational Medicine Magister (ILUNI MKK FKUI), Medical Faculty, Universitas Indonesia

Email address

:ray.basrowi@gmail.com
}

was including 13 death cases and 7 among them were showing heat stress with moderate workload. According to this report, one of the potential medical condition suffered by outdoor workers are heat stress. ${ }^{1}$

Numbers of studies showed that there were strong correlation between occupational related heat stress and workers' hydration status. Unfortunately, there were still very limited recommendation and guideline specifically regulated the importance of hydration toward outdoor worker as well as those who were working in high temperature working environment.

\section{Occupational Heat Stress: Definition and How It Affects Physiology of Worker}

Occupational heat stress defined as a net load to which a worker exposed from the various or combined factors or exposures of metabolic heat, 
environmental factors and clothing worn which was results in an incremental heat storage in the body. ${ }^{2}$ Heat stress leads to various heat-related illnesses such as heat stroke, hyperthermia, heat exhaustion, heat cramps or heat rashes. ${ }^{3} \mathrm{~A}$ mild and moderate heat stress usually less serious and did not harm general health condition, however it could cause individual fatigue and unfocused, which will interfere the working performance and productivity. Heat stress will had caused physiologic response of the body, as it needs to reduce the increased temperature inside the body, this is known as heat strain condition. ${ }^{4}$

Skin evaporation through sweating were the most dominant mechanism of the body in order to reduce the elevated body temperature. Apart of ambiance temperature, the impermeable clothing would also prevent the normal body evaporation mechanism. ACGIH has defined threshold value for working in hot place to maintain the body's core temperature in $+1^{\circ} \mathrm{C}$ from normal temperature $\left(37^{\circ} \mathrm{C}\right)$. The limit of body's core temperature can be excessive under certain conditions with selected populations, environment and physiological monitoring and other controls. Assessment in evaluating whether a worker in extreme hot environment experiences heat stress and heat strains is very important for health professionals to prevent the occurrence of disease caused by heat (Table 1).

\section{Central nervous system}

The central nervous system is responsible for the function of thermoregulation. The hypothalamus as part of the central nervous system structure acts as a location to control body temperature. The anterior hypothalamus acts as a thermostat and posterior hypothalamus as a determinant of the set point of core body temperature and initiates a normal physiological response to temperature changes. The ratio of sodium and calcium plays an important role in regulating this thermoregulation system. The posterior hypothalamus is responsible in physiological mechanism to maintain body temperature. When the ambient temperature exceeds the set point, through the sympathetic nervous system, the blood vessels will expand and the sweating process begins, intended to restore body temperature to normal. ${ }^{6}$

\section{Working capacity and muscle work activity}

The proportion of aerobic capacity needed to do certain jobs. First, the cardiovascular system will respond to increase oxygen demand when working in a hot environment by increasing pump volume (stroke volume) and heart rate. When stroke volume achieved, an increase need for cardiac output done by increasing the heart rate. Problems will arise if the work intensity is high enough in the hot place and carried out for a long time. Second, muscle work activity is associated with an increase in muscle temperature and will have an impact on the body's core temperature, which in turn will affect the thermoregulation control. Third, the high workload in a hot environment can result in insufficient oxygen tissue demand. ${ }^{7}$

\section{Circulation system}

The circulation system is responsible in oxygen distribution and nutrients to all body's tissue. In certain conditions, the heart is unable to fulfill oxygen and body heat expenditure needs. The autonomic nervous system and endocrine system will help blood flow to overcome this need. ${ }^{8}$

\section{Sweating mechanism}

Sweat glands founded in almost all skin tissue. This gland stimulated by sympathetic nerve and produce hypotonic fluid out of the skin surface. Sweat production up to $1 \mathrm{~L}$ /hour in industrial worker recorded and illustrated a large body cooling process. Each liter of sweat produced represented $580 \mathrm{kcal}$ of heat to the environment. Too much sweat loss will threaten the function of thermoregulation due to a decrease for body fluids progressively and if the body fluids is not replaced immediately, the body temperature will rise rapidly. The main composition of sweat is salt or sodium chloride. ${ }^{9}$ 
Table 1. Health effect to hot environment exposure

\begin{tabular}{|c|c|c|c|}
\hline Disorder & Cause & Symptoms & Treatment \\
\hline Heat Cramp & $\begin{array}{l}\text { Excessive sweating with } \\
\text { loss of body's salt }\end{array}$ & $\begin{array}{l}\text { - Ache, spasm in the } \\
\text { arm, feet and stomach } \\
\text { - Sudden } \\
\text { - Hot and moist skin }\end{array}$ & $\begin{array}{l}\text { - } \text { Drink water } \\
\text { - } \text { Massage in cramp area } \\
\text { - } \quad \text { Take a rest }\end{array}$ \\
\hline Heat Exhaustion & $\begin{array}{l}\text { Dehydration } \\
\text { non acclimatization }\end{array}$ & $\begin{array}{l}\text { - Excessive sweating } \\
\text { - Thirsty } \\
\text { - Pale, moist and cold } \\
\text { skin } \\
\text { - tachycardia } \\
\text { - Fatigue } \\
\text { - Fainted }\end{array}$ & $\begin{array}{l}\text { - Move to the shady area or } \\
\text { air conditioned room } \\
\text { - Take a rest with higher } \\
\text { feet } \\
\text { - Loosen the clothes } \\
\text { - Drink water }\end{array}$ \\
\hline Heat stroke & $\begin{array}{l}\text { Excessive heat exposure } \\
\text { and lead to body regulator } \\
\text { to malfunction }\end{array}$ & $\begin{array}{l}\text { - } \text { Body temperature } \\
\text { increase } \\
\text { - Sweat decrease } \\
\text { - Redden, hot, and dry } \\
\text { skin } \\
\text { - Breath difficulties }\end{array}$ & $\begin{array}{l}\text { - Emergency action } \\
\text { - Emergency call } \\
\text { - soak the patient in water } \\
\text { - Cold compression }\end{array}$ \\
\hline
\end{tabular}

Source: ACGIH TLVs \& BEI Book 2011

Salt requirement in normal people is 2.3-3 grams per day, but loss of fluid while working in moderate activities in hot environment reaches an average of 0.8 liters per hour, so the sweat that is produced every 8 hours can reach more than 6 liters per day, while sodium loss that comes out with sweat can reach 4.8-6 grams which is equivalent to $10-15$ grams of salt. ${ }^{10}$

Potassium loss in sweat can also lead to blood potassium deficiency, which will lead to heat stroke. Fluids replacement for loss of fluid due to sweating is very necessary. If fluid is not immediately given, there will be a shrinkage of the extracellular and interstitial spaces and plasma volume. Evidence show that sweat production is highly dependent on hydration status, so hypo hydration progression can be caused by excessive sweating and will increase body temperature which will lead to danger of heat stroke. ${ }^{9,10}$

\section{Heat acclimatization}

Workers exposed to heat will show distress signs and discomfort characterized by body temperature and pulse increase, headache, nausea and even fainting. The level of acclimatization determined by workers' physical fitness and the work period in the hot place. $^{11}$

\section{Heat Related Illness among Outdoor Workers}

When the body tries to tolerate hot temperatures, the body will experience heat stress, which manifests in body temperature and pulse increase. The body will compensate for the hot environment by sweating to reduce body temperature. If the humidity is high enough, the sweat will be difficult to get out, which prevents the body from releasing heat quickly. If this condition occurs continuously, workers can experience heat related illness such as heat cramps, heat exhaustion and even heat stroke that can lead to death. ${ }^{12}$

In a study conducted in several mining plant in Australia, reported that $40 \%$ of mining workers working in hypo hydration status (mild to severe), ${ }^{13}$ while in a study conducted in India of 58 firefighters, $20 \%$ of firefighters had a health impact 
caused by heat exposure in the form of heat exhaustion $18.3 \%$, heat cramps $6.2 \%$ and heat syncope at $4.1 \% .{ }^{14}$ Factors influence heat stress are age, sex, acclimatization, health status, body mass index, type of clothing used, direct exposure to sunlight, fluid intake, and workload. ${ }^{10}$

Of these factors, fluid intake is the easiest factor to control in preventing the effects of heat stress on workers. The type of fluid consumed to replace electrolyte loss due to sweating is a factor that needs to be investigated in an effort to prevent the effect of heat stress. The variation in the body's response to heat exposure varies from mild to severe. This disorder triggered by an increase in body core temperature with lack of fluid complication. The prognosis depends on rapid treatment to reduce body temperature and fluid and electrolyte intake (Table 1). ${ }^{9,10,13}$

\section{Hydration Status and Heat Stress in Outdoor Workers}

Most of the studies in heat acclimatization ${ }^{15-19}$ focused on physiological responses to heat. In terms of physiological adaptation, long-term heatacclimatized individuals are reportedly to have smaller rises in core temperature during heat exposure 20,21 and an advantage in body fluid regulation ${ }^{19}$, in which they indicate the ability to deal with stress from any given heat exposure..$^{22,23}$

Numbers of literature to date examining the effects of hydration status on cognition, exercise in the heat used as the dehydration protocol. Such studies typically result in hypo hydration of $\sim 2 \%$ body mass loss and have demonstrated decrements in various cognitive functions, including working memory, vigilance and perception. ${ }^{24-28}$ However, some studies have reported no effect of exercise induced hypo hydration on short-term memory, concentration and choice reaction time. ${ }^{29-31}$

In resting conditions, the body requires fluid intake of 2 liters per day, and in moderate physical activity, fluid requirements can increase to 3.5 liters per day. Fluid loss while working in moderate activities in hot environments reach an average of 0.8 liters per hour, so the sweat that is produced every 8 hours can reach more than 6 liters per day, while sodium loss that comes out with sweat can reach 4.8-6 grams which is equivalent to $10-15$ grams of salt. ${ }^{10}$

\section{Drinking and Rehydration to Treat Heat Stress}

Working in hot temperature environment, the body will be easily dehydrated due to sweat production as body mechanism to release heat generated from physical activity. Too much sweat production will release electrolyte. Salt is the most excreted electrolyte with an average loss of $4.8-6$ grams of sodium for 8 hours of working or equivalent to $10-$ $15 \mathrm{~g}$ of salt. Significant loss of electrolyte in the worker in extreme hot environment, need electrolyte replacement from fluid intake. Appropriate ion drink will provide a quick replacement for the body's electrolyte loss. ${ }^{32}$

Although the American College of Sports Medicine Guidelines on Nutrition and Athletic Performance recommend the amount of fluid intake. $^{33}$ In a recent study shows that deep-ocean water taken from the coast of Hualien, Taiwan at a depth of $662 \mathrm{~m}$ improves recovery following a dehydrating exercise, evidenced by accelerated recovery of aerobic capacity, increased lower-body muscle power performance and significantly reduced levels of exercise-induced muscle damage markers compared to participants drinking purified tap-water. ${ }^{34}$

Another study reported that a deep-ocean mineral water was shown to increase the exercise performance of gerbils, compared to distilled water, measured by retention rates during a 90-min treadmill exercise. ${ }^{35}$ Considering the established connection between hydration status and exercise performance, these data suggest that mineral water may provide optimal rehydration for performance recovery following high-intensity exercise. A study suggested that mineral water had the potential to improve lower-body muscle strength as well as acute rehydration rate after dehydrating exercise. ${ }^{36}$

\section{Conclusion}

Potential risk of heat stress and heat related illnesses are higher among outdoor and high temperature work place-based workers. The mechanism and pathophysiology of heat stress and heat related illnesses are well studied, however an 
intervention study focus on rehydration are still needed to demonstrate the benefits of it in reduce the heat stress and heat related illnesses in high risk population of workers.

\section{Conflict of Interest}

AM currently is The Leader of Occupational Health and Medicine Chief SKK MIGAS, RWB is Head of Medical Nutrition Services Department in Nestle Nutrition Institute Indonesia. Other author declares no conflict of interest.

\section{Open Access}

This article is distributed under the terms of the Creative Commons Attribution 4.0 International Licence (http://creativecommons.org/licenses/by/4.0/), which permits unrestricted use, distribution, and reproduction in any medium, provided you give appropriate credit to the original author(s) and the source, provide a link to the Creative Commons license, and indicate if changes were made.

\section{Reference}

1. Wulandari J, Ernawati M. Efek iklim kerja panas pada respon fisiologis tenaga kerja di ruang terbatas. The Indonesian Journal of Occup. Safety and Health 2017;6:207-215. doi: 10.20473/ijosh.v6i2.2017.207-215. [Google Scholar]

2. NIOSH Criteria for a Recommended Standard: Occupational Exposure to Heat and Hot Environments. 2016. doi:10.26616/NIOSHPUB2016106

3. CDC - Heat Stress - NIOSH Workplace Safety and Health Topic. www.cdc.gov. Retrieved 2016-04-15

4. Cuddy JS, Ham JA, Harger SG, Slivka DR. Effects of an electrolyte additive on hydration and drinking behavior during wildfire suppression. Wild and Env Med 2008; 19:172-180. [Google Scholar]

5. NIOSH. Recommendations for an occupational standard for workers exposed to hot environment. In: Occupational exposure to hot environment. US Department of Health and Human Resources. Revised criteria 1986. p.1-2

6. Center of Diseases Control and Prevention. Sodium: the facts. Division for heart disease and stroke prevention. 2011

7. NIOSH. Indices for assessing heat stress and heat strain. In: Occupational exposure to hot environment. US Department of Health and Human Resources. Revised criteria 1986. p.101-10

8. Ito T, Itoh T, Hayano T, Yamauchi K, Takamata A. Plasma hyperosmolality augments peripheral vascular response to baroreceptor unloading during heat stress. American Journal of Physiology-Regulatory, Integrative and Comparative Physiology 2005;289(2). [Google Scholar]

9. Center of Diseases Control and Prevention. Sodium: the facts. Division for heart disease and stroke prevention. 2011

10. ACGIH. Heat Stress and Heat Strain, In: TLVs and BEIs, Cincinnati: Signature Publication: 2008. 217-24.

11. Dang B, Dowell CH, Mueller C. Heat stress and strain evaluation among alumunium potroom employees. Health hazard evaluation report.2011:7

12. OSHA-NIOSH. Protecting worker from hot illness. Info sheet. DHHS (NIOSH): 2011174

13. Brake R. Fluid consumption, sweat rates and hydration status of thermally stressed underground miners and the implications for heat illness and shortened shift. Qld Ind Occ Health and Safety Conf. Townsville: 2001

14. Patel HC, Rao NM, Saha A. Heat exposure effects among firefighters. Indian Journal of Occ and Env Med 2006; vol 10. [Google Scholar]

15. Hori S, Ihzuka H, Nakamura M. Studies on physiological responses of residents in Okinawa to a hot environment. Jpn J Physiol 1976;26:235-44. [Google Scholar]

16. Hori S, Tsujita J, Tanaka N, Mayuzumi M. Studies on heat tolerance of subtropical natives after migration to a temperate zone. Int J Biometeorol 1978;22:82-93. [Google Scholar] 
17. Matsumoto T, Kosaka M, Yamauchi M, Yang GJ, Lee JM, Amador J, et al. Analysis of the mechanisms of heat acclimatization: comparison of heat-tolerance between Japanese and Thai subjects. Trop Med 1991;33:127-33. [Google Scholar]

18. Nguyen MH, Tokura H. Sweating and tympanic temperature during warm water immersion compared between Vietnamese and Japanese living in Hanoi. J Hum Ergol (Tokyo 2003;32:9-16. [Google Scholar]

19. Wakabayashi H, Wijayanto T, Lee JY, Hashiguchi N, Saat M, Tochihara Y. A comparison of hydration effect on body fluid and temperature regulation between Malaysian and Japanese males exercising at mild dehydration in humid heat. J Physiol Anthropol 2014;33:5. [Google Scholar]

20. Wakabayashi H, Wijayanto T, Lee JY, Hashiguchi N, Saat M, Tochihara Y. Comparison of heat dissipation response between Malaysian and Japanese males during exercise in humid heat stress. Int $\mathbf{J}$ Biometeorol 2011;55:509. [Google Scholar]

21. Wijayanto T, Wakabayashi H, Lee JY, Hashiguchi N, Saat M, Tochihara Y. Comparison of thermoregulatory responses to heat between Malaysian and Japanese males during leg immersion. Int $\mathrm{J}$ Biometeorol 2011;55:491. [Google Scholar]

22. Lee JY, Wakabayashi H, Wijayanto T, Hashiguchi N, Saat M, Tochihara Y. Ethnic differences in thermoregulatory responses during resting, passive and active heating: application of Werner's adaptation model. Eur J Appl Physiol 2011;111:2895. [Google Scholar]

23. Hellon R, Jones R, Macpherson R, Weiner J. Natural and artifical acclimatization to hot environments. J Physiol 1956;132:559. [Google Scholar]

24. Cian C, Barraud PA, Melin B, Raphel C. Effects of fluid ingestion on cognitive function after heat stress or exercise-induced dehydration. Int J Psychophysiol 2001;42(3):243. [Google Scholar]

25. Cian C, Koulmann N, Barraud PA, Raphel C, Jimenez C, Melin B. Influence of variations in body hydration on cognitive function: effect of hyperhydration, heat stress, and exercise-induced dehydration. J Psychophysiol 2000;14(1):29. Available from: https://doi.org/10.1027//0269 [Google Scholar]

26. Baker LB, Dougherty KA, Chow M, Kenney WL. Progressive dehydration causes a progressive decline in basketball skill performance. Med Sci Sports Exerc 2007;39(7):1114. Available from: https://doi.org/10.1249/mss.0b013e3180574 b02 [Google Scholar]

27. Gopinathan PM, Pichan G, Sharma VM. Role of dehydration in heat stress- induced variations in mental performance. Arch Environ Health 1988;43(1):15. [Google Scholar]

28. Sharma VM, Sridharan K, Pichan G, Panwar MR. Influence of heat-stress induced dehydration on mental functions. Ergonomics 1986;29(6):791. Available from: https://doi.org/10.1080/00140138608968315 [Google Scholar]

29. Edwards AM, Mann ME, Marfell-Jones MJ, Rankin DM, Noakes TD, Shillington DP. Influence of moderate dehydration on soccer performance: physiological responses to 45 min of outdoor match-play and the immediate subsequent performance of sportspecific and mental concentration tests. Br J Sports Med 2007;41(6):385. [Google Scholar]

30. Serwah N, Marino FE. The combined effects of hydration and exercise heat stress on choice reaction time. J Sci Med Sport 2006;9(1-2):157. doi: org/10.1016/j.jsams.2006.03.006. [Google Scholar]

31. Tomporowski PD, Beasman K, Ganio MS, Cureton K. Effects of dehydration and fluid ingestion on cognition. Int J Sports Med 2007;28(10):891. Available from: https://doi.org/10.1055/s [Google Scholar]

32. Marimoto T, Itoh T, Takamata A. Thermoregulation and body fluid in hot environment. Prog Brain Res 115: 499-508, 1998 
33. Thomas DT, Erdman KA, Burke LM. American College of Sports Medicine joint position statement. Nutrition and athletic performance. Med Sci Sports Exerc 2016;48(3):543. [Google Scholar]

34. Hou CW, Tsai YS, Jean WH, Chen CY, Ivy JL, Huang CY, et al. Deep ocean mineral water accelerates recovery from physical fatigue. J Int Soc Sports Nutr 2013;10(1):7. [Google Scholar]
35. Wang ML, Chen YJ, Cheng FC. Nigari (deep seawater concentrate) enhances the treadmill exercise performance of gerbils. Biol Sport 2014;31(1):69. [Google Scholar] 36. Keen DA, Constantopoulos E, Konhilas JP. The impact of post-exercise hydration with deep-ocean mineral water on rehydration and exercise performance. J Int Soc Sports Nutr 2016;13:17. [Google Scholar] 